\title{
THE STATE OF THE AMERICAN FAMILY: THE PARADOX OF HOW FAMILIES AND FAMILY VALUES ARE CHANGING WHILE STAYING THE SAME*
}

\author{
J. DeFrain \\ University of Nebraska-Lincoln \\ NE 68588-0236 USA \\ (e-mail: jdefrain1@unl.edu)
}

\begin{abstract}
How is the American family doing today? The answer depends upon whom you are talking with and the social/political/cultural lens you are looking through. This article is written by an American professor emeritus of family studies who has studied and taught about families for more than forty years. The author has been married to his wife Nikki for fifty years and they have raised three daughters and are now active in an extended family which included four grandchildren and three sons-in-law. In this article, the author avoids talking about families from a political perspective because in America this kind of talk usually generates more heat than light. Even though the American media tends to focus only on problems and give all of us the impression that families in particular and life on the planet in general are in grave danger, after studying strong families in the U.S. and around the world for more than forty years, the author personally believes that the majority of families in America are doing well and are satisfied with their life together. Some families are just doing okay. And some, of course, are in deep trouble. Truth be told, all American families have problems, just as all families around the world have problems. And, as it is true from a global perspective, not all families in the U.S. are strong families. But all families in the U.S. have strengths and they use these strengths in their efforts to meet the challenges their family inevitably faces. In this article, the author begins looking at American families today from the top-down perspective - the macro-level - and follows that with a discussion from the bottom-up perspective the micro-level. These two perspectives complement each other and give us a reasonably good answer to the question of how the American family is doing today. And these two perspectives give us a better understanding of the paradox that families and family values are changing in some ways while we stay, deep-down, basically the same in our families.
\end{abstract}

Key words: family; American family; political perspective; global perspective; top-down perspective (macro-level); bottom-up perspective (micro-level)

Professionals who study families in America and people who have an opinion about families — which includes just about everyone — have sometimes been broadly divided into two different camps: the optimists and the pessimists. Like many others fascinated by families, I like to think of myself as neither an optimist or a pessimist, trying instead to be a realist about families in our country. There is also controversy in our country between proponents of continuity in families and proponents of change. Some observers are dismayed and angered by the unceasing changes in American society; some channel these emotions into political activity; some welcome many of these changes; and some are too busy caring for their children and elderly parents and paying the bills to spend

* C J. DeFrain, 2017. 
time talking about what they see as largely theoretical issues that they cannot control anyway.

These back-and-forth dynamics between continuity and change have always been apparent in the U.S. and no doubt will continue through the coming decades. Especially during political campaigns in which politicians like to stir up controversy to attract their most enthusiastic partisan voters to the polls. Most of the time the majority of Americans do not talk about hot-button issues such as abortion or gay rights. In the U.S. politics, religion, and sexual issues are often seen as private issues that should remain outside the realm of public scrutiny. The average American much more is focused on her or his own personal and family challenges, i.e., they do not understand their wife/husband; their children do not understand them as parents; they as adult children do not understand their aging parents; and how are we going to make ends meet this month. If you are skeptical about what I am saying, please come to America and talk face-to-face with everyday people on the street. What we call the general public. You will quickly see what I mean. And yes, it is true that families in many ways are changing and some of these changes are alarming to many observers and simply a fact of life to other observers. And it is also true that families, deep-down, in many ways are the same. Especially in regard to the internal dynamics of the family - how they function behind closed doors in the family, the most intimate of environments. By looking from both angles - the macro- and micro-perspectives - this will help us better understand the paradox of how families and family values are changing while at the same time remaining the same.

\section{THE BIG PICTURE - THE MACRO-LEVEL PERSPECTIVE ON FAMILIES}

Let us begin looking at families in the U.S. from the top down. Here is a selection of statistics focusing on marriage and family issues today in America:

- $85 \%$ of the U.S. population will marry at least once [28].

- Age at marriage has been on the increase for more than four decades. In 1960, the median age for a first marriage was 22.8 years for men and 20.3 for women. In 2009 , the median age for first marriage was 28.4 years for men and 26.5 years for women [30].

- Over $75 \%$ of Americans report a belief that being married is an important value [24].

- Marriage among those with college degrees appears to be getting stronger, while marriage among those with a high school degree or less is becoming increasingly unstable and unhappy [24].

- In 2010, there were 2,096,000 marriages and 872,000 divorces [8].

- $\quad 23.2$ million Americans - about 9.1\% of the U.S. population — are currently divorced [29].

- People marrying today have a $40-50 \%$ chance of divorcing. Statistically, $40 \%$ of first marriages, $60 \%$ of second marriages, and $73 \%$ of third marriages end in divorce $[24 ; 27]$.

- About $75 \%$ of those who divorce will eventually remarry [28].

- Of the marriages that do not end in divorce, the quality of some of those may be poor [24]. 
- After 10 years of marriage, it has been predicted that only $25 \%$ of couples will still be happily married [24].

- Most divorces involve children, and more than 1 million children are affected by divorce each year [28].

- Approximately 40\% of children will experience divorce before adulthood [4].

- Women are more likely than men to file for divorce [24].

- Most adults adjust well to divorce over time: 30\% feel their lives were negatively impacted [17].

- Divorce and unmarried child bearing are highly related to child poverty [25].

- A small number of studies have found positive individual benefits of divorce such as greater autonomy, personal growth, and happiness [5].

- Married people live longer than unmarried or divorced people [31].

- Married people are happier than single, widowed, or cohabiting people [31].

- Married people have more sex and a better quality sexual relationship than do single, divorced, or cohabiting individuals [31].

- Married people are more successful in their careers, earn more, and have more wealth than single, divorced, or cohabiting individuals [7; 31].

From my perspective as a family researcher and counselor, domestic violence, alcohol-related problems, and the abuse of other drugs are especially worrisome. A wealth of national statistics compiled by the National Coalition Against Domestic Violence [14] gives a grim picture of domestic violence in the United States. On average, nearly 20 people per minute are physically abused by an intimate partner in the U.S. During one year, this comes to more than 10 million women and men. One in three women and one in four men have been victims of some form of physical violence by an intimate partner within their lifetime. One in five women and one in seven men have been victims of severe physical violence by an intimate partner in their lifetime. On a typical day, there are more than 20,000 phone calls to domestic violence hotlines nationally. $19 \%$ of domestic violence incidents involve a weapon of some kind. The presence of a gun in a domestic violence situation increases the likelihood of homicide by 500\%. Women 18 to 24 years of age have the highest risk of abuse by an intimate partner. Only $34 \%$ of those injured by intimate partners receive medical care for their injuries. One in five women and one in 71 men in the U.S. have been raped in their lifetime. Almost half of female victims of rape $(46.7 \%)$ and male victims of rape $(44.9 \%)$ were raped by an acquaintance. Of these, $45.4 \%$ of female rape victims and $29 \%$ of male rape victims were raped by an intimate partner. $72 \%$ of all murder-suicides involve an intimate partner, and $94 \%$ of the victims of murder-suicide are females. 1 in 15 American children are exposed to intimate partner violence each year, and $90 \%$ of these children are eyewitnesses to the violence [14].

The physical and mental impact of intimate partner violence is also considerable. Women abused by their partners are more vulnerable to contracting HIV and other STI's because of forced intercourse or prolonged exposure to stress. Domestic victimization is correlated with a higher rate of depression and suicidal behavior. Physical, mental, and sexual reproductive health effects have been linked to domestic violence, including adolescent pregnancy, unintended pregnancy in general, miscarriage, stillbirth, intra- 
uterine disorders, chronic pain, disability, anxiety, and post-traumatic stress disorder (PTSD). Add to these noncommunicable diseases such as hypertension, cancer, and cardiovascular diseases. Victims of intimate partner violence are also at increased risk for developing addictions to alcohol, tobacco, and other drugs [14].

Alcohol is the most widely used psychoactive drug in the United States. It contributes to the death of 88,000 people every year. Approximately 62,000 men and 26,000 women die, making it the third leading cause of preventable death in this country after tobacco and diet/activity patterns. Based on victim reports, $37 \%$ of the rapes and sexual assaults in America involved alcohol use by the offender. Fetal alcohol syndrome (FAS), which can occur when women drink during pregnancy, is the leading known environmental cause of mental retardation in Western countries. And, it is estimated that more than $10 \%$ of U.S. children live with a parent with alcohol problems $[3 ; 4 ; 9]$.

About 570,000 people die every year due to drug use. Breaking this down, 440,000 die from disease related to tobacco; 88,000 due to alcohol; 20,000 due to illicit (illegal drugs); and 20,000 due to prescription drugs [1; 3]. Looking at those numbers from another angle, they tell us that only $3.5 \%$ of drug-related deaths in our country each year are related to the use of illegal drugs, leaving $96.5 \%$ of the deaths caused by legal drugs. Why in our society do we focus so much attention on illegal drugs, when legal drugs kill so many more people?

More than 40 years ago when I began my career as a newly-minted Ph.D. in family studies from the University of Wisconsin-Madison, most Americans believed that the American family was in crisis. With a divorce rate reaching about $50 \%$, how could the family survive? Along with this, new groundbreaking research on child abuse, spouse abuse, alcohol and other drug problems in families, and, finally by the early 1980s, studies of sexual abuse in families were appearing regularly in professional journals and the media. This came as a shock to many Americans. But many others were relieved to see the light finally starting to shine in on the family. For the family had long been a private place, a place in which good things and bad things happened, but no one wanted to talk about the bad things. There was an impermeable zone of privacy surrounding the family and one simply did not discuss family problems outside the family. "A man's home is his castle," Americans often said back then. But the problem is that abuse and unhappiness can thrive in the shadows.

Just before I rose to walk across the stage and receive my doctorate in 1975 at the University of Wisconsin-Madison, my adviser Dr. William H. Marshall said to me, "You know, John, I wish I were graduating with my doctorate today." "Why?" I asked. Bill replied, "Because when I began my career in 1958, we couldn't talk about family problems. We couldn't really study in an honest way what was happening in families. Inside the family was all hidden from view. Today, you are able to look at the American family honestly, and that is very important." Looking openly and honestly at American families is important because we cannot solve family problems if we cannot talk about them, study them, and look for solutions. Think about it: If you have cancer, do you have any chance at all of getting some help if you cannot talk about it? It is really as simply as that. 
So, fast-forward the American story to today. Are American families doing better than in 1975 when I graduated? Yes, I think so. Because we as a society have become more honest about facing family problems, we have begun working together to solve these problems. There have been, literally, thousands upon thousands of studies of families in our country, and these research projects have led to the development of countless programs to help strengthen marriages and families, to prevent child abuse and spouse abuse, to help stop alcohol abuse and the abuse of other drugs, to teach positive parenting and for enriching marriages [23]. Are American families perfect today, living in harmony with the sun shining all around them without end? Of course not. Today as a country we continue to have serious problems in families but we also have the knowledge at hand to deal with couple and family problems quite skillfully. Amazing progress has been made, and it has been a pleasure to think about what has happened over the years.

\section{FAMILIES FACE-TO-FACE: THE MICRO-LEVEL PERSPECTIVE}

From the bottom-up perspective, the micro level, you get a different but complementary perspective on the state of the American family. As a researcher for the past forty years I have been studying families from the ground up — face-to-face. Working with a growing international team, we have studied family strengths and challenges from a worldwide perspective - more than 30,000 family members have been involved in these studies of family strengths and challenges in 42 countries around the world, representing all of the world's major geo-cultural areas, including Africa, Asia, Europe, Latin America, the Middle East, North America, and Oceania. Dr. Vladimir Zubkov, formerly on the faculty of Peoples' Friendship University of Russia, can be credited with the first studies of families from a strengths-based perspective in Russia [33]. The family is the most intimate environment in the world, and has been rightfully called the most difficult social institution to study because it has been so closed from the view of outsiders. The research teams around the world I have been working with for many decades focus on the strengths of families, the challenges families face, and the story of how families use their strengths to meet these challenges in life.

Looking at families worldwide from the micro perspective, our research teams have developed over the years an international family strengths-based perspective. Here are some of the things we have learned about families in our research in the U.S. and around the world:

- Look for problems in a family and you will find only problems. Look for strengths and you will also find strengths. Most of the time human beings around the world tend to focus on a family's problems. However, to get a more accurate picture of a family you need to look both at strengths and challenges. If you do not consider a family's strengths, you get an inaccurate and negatively-skewed view of the family. Also, the family needs to think about their strengths, because they will use these strengths as a team to solve their problems.

- All the problems in the world either begin in families or end up in families, according to my friend and colleague Dr. David H. Olson at the University of Minneso- 
ta - St. Paul [13. P. 294]. Sometimes families create their own problems, and sometimes families have problems thrust upon them from the outside.

- Either way, every society needs to attend to the needs of families in all their wonderful diversity, because families are the foundation for every society. All families are unique and different, and all families need to be carefully nurtured and supported because families are the glue that holds society together. Strong families are the foundation of strong cultures.

- Function, not structure, is most important. When talking about families, it is common to make the mistake of focusing on external family structure or the type of family, rather than focusing on internal family functioning. People often say twoparent families are better than one-parent families. But if you look closely inside the family, you often see something quite different. For example, is a two-parent family with an alcoholic father who terrorizes his family with words and his fists really stronger than a stable and happy single-parent family in which the mother and children feel safe and secure and genuinely love each other? Or, is a heterosexual couple in which the husband is chasing women at the office a stronger relationship than two women living together who genuinely love each other and are committed to the partnership?

- Families around the world are incredibly diverse. In one study in Australia, we identified a group of families who believed they were strong families, who said they were happy together as a family, who were satisfied with their relationships with each other, and who believed they loved each other. We asked the families to describe the various family structures in which they lived: two-parent family, singleparent family, extended family, a family with heterosexual and gay members, and so forth. We were amazed to find that the families that described themselves as strong families could be categorized in 32 different structures. Though the so-called "ideal" and "traditional" family in the Western world might be seen as a family with "Mom, Dad, and the kids", the reality is much different. There are many kinds of family structures that are strong.

- Strong marriages and intimate partners are the center of many strong families. The couple relationship is an important source of strength in many families with children who are doing well. Parents need to find ways to nurture a positive couple relationship for the good of everyone in the family.

- Strong families tend to produce great kids.

- If you grew up in a strong family as a child, it will probably be easier for you to create a strong family of your own as an adult. But it is also quite possible to do so if you were not so lucky and grew up in a seriously troubled family [26].

- The relationship between money and family strengths is weak. Once a family has adequate financial resources, the relentless quest for more money is not likely to increase the family's quality of life, happiness together, or the strength of their relationships with each other.

- Strengths develop over time. When couples start out in life together, they sometimes have considerable difficulty adjusting to each other, and these difficulties are quite 
predictable. Adjusting to each other is not an easy task. Many couples who are unstable at first end up creating a healthy, happy family.

- Strengths are often developed in response to challenges. A couple and family's strengths are tested by life's everyday stressors and by significant crises all of us face sooner or later.

- Strong families do not think much about their strengths, they just live them. It is, however, useful to carefully examine a family's strengths from time to time and discuss precisely how family members use these strengths to great advantage.

- Not all families are strong, but all families have strengths. Among the most troubled families I know are those families in which there are problems related to alcohol and other drug abuse, violence in the family, and sexual abuse of children in the family. These are the families that have caused me the most concern over the years. But even in these families there are remarkable things happening, good things happening. For example, though a dominant family member may be physically, emotionally, or sexually abusive, other family members may be demonstrating considerable courage in their efforts to protect the more vulnerable individuals in the family from harm.

- Strong families, like people, are not perfect. Even the strongest of families have difficulties and disagreements. A strong family is a work of art continually in progress, always in the process of growing and changing.

- When seeking to unite groups of people, communities, and even nations, uniting around the cause of strengthening families can be a powerful strategy: a worldwide building family strengths movement.

- Human beings have the right and responsibility to feel safe, comfortable, happy, and loved.

\section{STUDYING STRONG FAMILIES AND FAMILY STRENGTHS WORLDWIDE}

As I write this article, one of our most extensive studies of international family strengths continues in the Middle East. Our team includes researchers assembled by the Doha International Family Institute in Qatar. So far, after working together for three years the team has interviewed families in Jordan, Tunisia, Qatar, and Oman. If all goes well, we will be working together for several more years and eventually hope to be able to write a book on The State of the Arab Family in all 22 Arab nations in the Middle East. That is the dream. The four most important questions we are trying to answer in this large-scale study are: 1) What are the strengths of Arab families today? 2) What are the challenges that Arab families face today? 3) How do Arab families use their strengths to meet the challenges they face? 4) How can neighborhoods, nations, regions, and the global community work together to help strengthen families in the Middle East and around the world?

A major consideration when doing a study of this nature is how you are going to gather a sample of participants. First of all, are you going to study families who have identified themselves as strong families, or are you going to study the strengths of fami- 
lies in general. Over the years we have used both approaches: identifying a sample of families who believe they are strong families, who are happy with their lives together, who are satisfied with family relationships, and who believe they love each other. This approach gathers together a remarkable collection of families. Another approach is not to look at so-called strong families, but instead to look at a wide variety of families and, on the assumption that all families have strengths, to have these families identify their strengths and describe how they use their strengths to good advantage.

In the current study in the Middle East, we have chosen to gather a broad sample of families and look at their strengths, rather than gathering a relatively narrow sample of families who think of themselves as strong families. The study of Arab families is a mixed-methods study, using both qualitative and quantitative research methods. We begin by gathering focus groups together. These focus groups include a diverse group of males and females, young and old, rich and poor, rural and urban, religious and secular, representing many different ethnic and cultural groups in each country. They are asked to discuss the strengths of their family, the challenges they face together, and to tell stories of how the family used their strengths to overcome the difficulties they faced. The focus groups are conducted in a relatively unstructured, open and free-flowing manner.

From the information obtained in the focus groups a formal interview protocol is developed, and the first draft of an Arab Family Strengths Inventory is constructed. These are then used in the next stage of the study: interviews with individual families focusing on their strengths and challenges, and asking them to fill out the Arab Family Strengths Inventory, which has a list of 60 family strengths to think about. Final stages of the longterm research project will focus on quantitative analysis of data from large samples of families in each country.

The best way to gain a personal understanding of the qualities of strong families is to fill out a family strengths inventory for yourself. If you are interested, please take a look at the University of Nebraska web site: http:/extensionpublications.unl.edu/assets/ pdf/g1881.pdf. There you will find the American Family Strengths Inventory. You can print it out for free, and fill it out with your own family in mind. Remember, of course, that this particular family strengths inventory is from an American perspective, but I think you will quickly see that it also works very well for people from other cultures, for family strengths worldwide are remarkably similar — certainly much more similar than different.

Currently we are working on reports on family strengths and challenges in Qatar, Jordan, and Tunisia. For the past several months, we have been immersed in reading transcripts of the focus group dialogues and reading the stories from family members about challenges they have faced in life and how they used their strengths to overcome these challenges. What never ceases to amaze us is how familiar these stories seem to us. Listening to the Arab families telling their stories, it is striking how much they sound like American families talking. Just like the Americans, the Arab families tell about problems that begin in the family: their difficulties in communication between husbands and wives, parents and children, and disagreements in the extended family. They also tell 
stories of how the family faces difficulties that end up in the family, problems forced upon the family from the outside: unemployment, poverty, war, health difficulties, and so forth. Though the environment in the Middle East is clearly different from the environment in America today, the intimate life of American families and Arab families has extraordinarily similar dynamics. And the strengths of Arab families look startlingly similar to the strengths of American families.

This is not a surprise to us, because we have been seeing these similarities since 1982 when we began our first international family strengths studies in 12 Latin American countries. Constanza Casas, a graduate student from Bogota, Colombia rushed into my office one morning and exclaimed: "John! John! The strengths of Latin American families are the same as the strengths of American families!". "Baloney", I muttered. "People are all different around the world." Constanza told me that no, I was wrong. Over the coming weeks, she translated the findings from Spanish to English for me and I got to read for myself what Latin American family members were saying about the qualities that made their families strong. And Constanza was right: the Latin Americans were saying the same things as the North Americans [12].

I have now seen this phenomenon for more than 35 years in studies all around the world, and I must admit that it still never fails to surprise and move me. In our most intimate environment - the family - human beings around the world are much more similar than different. Years ago, I was visiting a small Outback country town in the Top End of Australia. I was talking with a lovely and wise Aboriginal Australian social worker, and I was excited to tell her about the strengths of families around the world and how these strengths were much more similar than different. In fact, I really did not think there was any important difference at all when you look at strong families from country to country and culture to culture. The Aboriginal social worker looked at me skeptically. Her body language and eyes were saying, "How dumb can this American professor really be?" Finally, she could not stand it anymore and blurted out, "Well, John, of course the strengths are the same all around the world. We're all human beings, you know!". I loved her honesty. I loved how she quickly recognized professors could miss the point. And I agreed, speaking softly: "Yes, we are all human beings".

But when you look at the world today and see all the conflict among cultures and countries, it remains clear that as human beings we often forget our similarities, accentuate our differences, get into nasty tribal battles with each other, and forget our basic and deep-down oneness as human beings. We continue to make the mistake of thinking that people are really different because they dress different, speak a different language, listen to different music, eat funny food, call God by different names, and live in a very different physical environment. But in the final analysis, people are people and families are families. We forget this truth at the peril of our world.

Our International Family Strengths Model has six major qualities. Broadly speaking, these six strengths describe families in every country and culture we have studied over the years: appreciation and affection for each other; positive communication; commitment to the family; enjoyable time together; a sense of spiritual well-being and shared values; the ability to manage stress and crisis effectively. The family strengths inven- 
tories that we develop for each unique country or culture are all different, and tend to have 60 to 90 strengths listed for the family members to assess. But the instruments from country to country and culture to culture bear remarkable similarities. Below is a list of the six broad family strengths that are common around the world, and sub-qualities for each of the six strengths.

\section{International Family Strengths}

1. Appreciation and affection

Caring for each other

Friendship

Respect for individuality

Playfulness

Humor

3. Positive communication

Giving compliments

Sharing feelings

Avoiding blame

Being able to compromise

Agreeing to disagree

5. Spiritual well-being and shared values

Hope

Faith

Compassion

Shared ethical values

Oneness with humankind

Oneness with the Earth
2. Commitment to the family

Trust

Honesty

Dependability

Faithfulness

Sharing

4. Enjoyable time together

Quality time in great quantity

Good things take time

Enjoying each other's company

Simple good times

Sharing fun times

6. The ability to manage stress and crisis

effectively

Adaptability

Seeing crises as both challenges and opportunities

Growing through crises together

Openness to change

Resilience

Over the years, we have worked with many statisticians around the world who have used a wide variety of sophisticated statistical techniques to develop this model of international family strengths. We also simply apply our own logical thinking abilities as we separate strengths into various groupings. Using a technique called factor analysis the statisticians have come up with family strengths models with 6 factors, 4 factors, 2 factors, even 1 factor. The statisticians tell us that the various family strengths are all so very closely related to each other that, in the final analysis, it is very difficult to separate them out individually. For example, a family with positive communication is quite likely to spend enjoyable time together and to express appreciation and affection for each other while having the ability to deal with stress and crisis effectively. So, you can think about 60 or 85 or 90 sub-strengths, or 4 or 6 major family strengths, or you can think about how all these fit together into one over-arching strength. We call this all-encompassing strength positive emotional connection or love. In sum, all the strengths are highly related to each other, and if a family has one strength it is quite likely to have several other important strengths. We envision a ball of twine with all the strengths wrapped around each other and intimately connected. 


\section{WHAT IS A FAMILY AND WHAT IS A STRONG FAMILY?}

One American dictionary defines family this way [16]: 1) a group of people who are related to each other; 2) a person's children; 3) a group of related people including people who lived in the past. Of course, there are countless other definitions of family. Here are some I have chosen to reflect the diversity of perspectives:

- A family consists of two or more people (one of whom is the householder) related by birth, marriage, or adoption residing in the same housing unit [30].

- The term is inclusive for people who "care, support and protect each other" [15].

- ...A family is a group of two or more people that are related by blood, marriage (registered or de facto), adoption, step or fostering, and who usually live together in the same household. This includes all families such as newlyweds without children, same-sex partners, couples with dependants, single mothers or fathers with children, and siblings living together. At least one person in the family has to be 15 years or over. A household may contain more than one family [8].

- A family is defined as two or more persons who share resources, share responsibility for decisions, share values and goals, and have a commitment to one another over time [6].

- Definitions of the family vary along a continuum with biological conceptions on one end of the continuum and social conceptions on the other [18]. Having a child through birth would be on the biological end, and adopting a child would be on the social end of the continuum. Both are legitimate definitions of family. Voluntary family or voluntary kin: people who care for us, support us, and feel like family to us, but are not related by blood or law [11].

- Call it a clan, call it a network, call it a tribe, call it a family. Whatever you call it, whoever you are, you need one [20].

Here is how we define a strong family: people who share significant relationships strengths, which are likely to include appreciation and affection for each other; commitment to the family; positive communication with each other; enjoyable time together; a sense of spiritual well-being and shared values; and the ability to manage stress and crisis effectively. Frankly though, I like this short, simple, and elegant definition the best: strong family - people who love and care for each other.

The list of things we can do to help strengthen families is endless. It is also important to note that there is not one best place to begin dealing with global family challenges. The work needs to be done on many levels and in many different ways. Here are a few things to do that immediately come to mind. We encourage the reader to generate her or his own list:

- Because families are the basic foundational social unit in all human communities around the world, and healthy individuals within healthy families are at the core of a healthy society, it is in everyone's best interest, then, to help create a positive environment for all families. This can be done by linking all of our social institutions: educational institutions, businesses, human and family service agencies, religious institutions, health organizations - literally everyone involved in the daily life of a community. 
- Solutions to global family problems will not be easy. Because all problems either begin or end up in the family, family problems need to be addressed from both the macro- and micro-perspectives. Successful work with families is done face-toface on the micro-level as a counselor helps a young couple learn how to parent their child positively and effectively. And successful work to help strengthen families is also done on the macro-level when international coalitions of governments find ways to bring peace to war-torn countries or stabilize broken financial systems while simultaneously preserving threatened social safety nets.

- It is important to point out that the relationship between money and family strengths is tenuous at best. In cultures in which economic resources are relatively plentiful, there can still be serious couple and family problems. The United States and Korea are seen as affluent nations compared to many other countries around the world, and yet the divorce rates in these countries are among the highest in the world [13; 32]. Even as countries develop economically, family problems will not necessarily tend to decrease. Rather, the nature of the problems will change.

- Strong marriages are the foundation of many strong families, and many marriages around the world are experiencing difficulties today. Part of the challenge of building family-friendly communities is to also build marriage-friendly communities. One good way to do this is to create couples enrichment courses and activities, emphasizing the importance of healthy couple relationships. These types of programs can be developed by creating partnerships among various local institutions, including schools and colleges, religious institutions, volunteer groups, and family-service organizations.

- Involving fathers in the day-to-day life of families is crucial. Mothers should not have to carry all the burdens of childrearing alone. And fathers should not only take on the responsibilities, but have the opportunity to experience joyful feelings as they watch children grow and learn. Also, the difficult process of parenting can disrupt the marital bond. So, it is important to note that, "The best thing a father can do for his children is to love their mother". And, by the same token, "The best thing a mother can do for her children is to love their father". Since the couple relationship is the foundation of a two-parent family, the needs of the marital relationship have to be carefully nurtured.

- The strengths of single-parent families need to be recognized and acknowledged. Countless single-parent families are strong and emotionally healthy. Besides, in many cases involving violence, sexual abuse, alcohol, or other drug abuse, it is probably best that a parent with any of those problems or behaviors be out of the picture to insure the rest of the family's personal well-being and safety. Programs to support single-parent families are essential.

- Endless political bickering which frames family challenges in black-and-white, good-versus-evil, right-versus-left terms will not help the situation. If it is true that all the problems in the world either begin in families or end up in families, it becomes clear that blaming families for everything does not make sense. Nor does it make any sense to blame society for all of the problems families face. Some problems are generated internally in the family, some come from outside the family, and most problems are probably a combination of causes coming from multiple 
sources. Deciding whom to blame is a hopeless discussion to get into. The question should be, "How can we work together as families, communities, and nations to make the world better for everyone?"

- Local neighborhoods, communities, and even nations often get stuck, doing the same things over and over with poor results. By joining with others on the national and international levels to discuss common couple and family problems we can help each other think outside the box, making it possible for us to develop genuinely new solutions to old problems.

$$
* * *
$$

Much of the discussion in America about families circles around the good old days, whatever and whenever that might been. In my family, I often think about the good old days. Were the good old days when my grandmother was a six-month-old baby on the farm in south-central Nebraska? Were the good old days when her parents arrived in a horse-drawn wagon in 1884 and they constructed a dug-out — basically a dirt hole in the side of a hill with a few boards in the front - to live in for their first year on the Great Plains. As the family legend goes, when Grandma Effie DeFrain was a baby and toddler, the dug-out was divided into two rooms: on the right side of the dug-out the family slept - my great-grandfather, my great-grandmother, my grandmother Effie as a baby and small child, and her brothers and sisters. And on the left side of the dugout, separated by a buffalo skin, the farm animals slept. All slept together, for the sake of warmth in cold winters.

Or were the good old days when my father left the farm in 1936 and went to the University of Nebraska, the first of his family to go off to college. When Dad met Mom at a dance that year, he had to hold his hand over his mouth when he smiled and talked with her because he had a large gap where his four top front teeth used to be. Poor farm families in the Great Depression of the 1930s did not have money for dental care, and hardly any money to go to college. Dad swept floors in a tavern in Lincoln, Nebraska for a year before he saved enough money to get false teeth so he could show Mom his nice smile.

And what about today? My wife Nikki and I have three grown-up daughters who all have families of their own. Each daughter has a good husband, beautiful children, and yet all these three young families struggle with problems at work and money problems at home. Is today a perfect time in the life of our family? Of course not. But objectively speaking, is it better today than when my parents were growing up or my grandparents were growing up? Of course, it is. Education and economic progress have made the difference.

Putting all of this into perspective, it is clear to me that when we chatter endlessly about the state of the American family, it is easy to miss the point. Yes, the pessimists are correct: all families have problems today, and they have had problems forever. And yes, the optimists are correct: all families have strengths today, and they have had strengths as long as human beings have walked the earth, which by everyone's estimate is a long, long time. We are left with a paradox: the more families change, the more they stay the same. Rather than continuing to bicker as pessimists or optimists, a more realistic ap- 
proach recognizes strengths and challenges that families all face. And the solution to these relentless and never-ending challenges is to focus on the strengths of each family, to use the family's strengths to meet the challenges they face, and to continue to grow as a caring society and develop social support programs that help families grow, change, and succeed.

\section{REFERENCES}

[1] Alcohol and public health (2016). http://www.cdc.gov/alcohol.

[2] Alcohol and sexual assault (2016). http://pubs.niaaa.nih.gov/publications/arh25-1/43-51.htm.

[3] Alcohol facts and statistics (2016). http://www.niaaa.nih.gov/alcohol-health/overview-alcoholconsumption/alcohol-facts-and-statistics.

[4] Amato P. Divorce and the well-being of adults and children. Family Focus. 2007: 52, F3-F4, F18.

[5] Amato P. The consequences of divorce for adults and children. Journal of Marriage and the Family. 2000: 62 (4), 1269-1287.

[6] American Association of Family and Consumer Sciences. AAFCS: Connecting professionals, touching lives (2015). https://www.aafcs.org/AboutUs/FAQ.asp.

[7] Antonovics K., Town R. Are all the good men married? Uncovering the sources of the marital wage premium. American Economic Review. 2004: 65 (1), 137-154.

[8] Australian Bureau of Statistics. What is a family? (2013) http://www.abs.gov.au/ausstats/ abs@.nsf/Products/6224.0.55.001 Jun\%202012 Chapter What\%20is\%20a\%20Family\%3F.

[9] Behavioral health trends in the United States: Results from the 2014 National Survey on Drug Use and Health (HHS Publication No. SMA 15-4927, NSDUH Series H-50). http://www.samhsa.gov/data.

[10] Berman J. What makes a family? Children, say many Americans (2010). http://abcnews.go.com/ $\mathrm{WN} /$ defines-family-children-Americans-survey/story?id=11644693.

[11] Braithwaite D. Braithwaite delves into voluntary kin (2008). http://scarlet.unl.edu/p=872.

[12] Casas C., Stinnett N., DeFrain J., Lee P. Family strengths in Latin America. Family Perspective. 1984. Winter.

[13] DeFrain J., Asay S.M. Strong Families Around the World: Strengths-based Research and Perspectives. London: Routledge/Taylor \& Francis Group; 2008.

[14] Empowering victims and survivors (2016). http://www.ncadv.org.

[15] Families in Australia. Canberra: Department of Prime Minister and Cabinet, 2008.

[16] Family. http://www.merriam-webster.com/dictionary/family.

[17] Hetherington E.M., Kelly J. For Better or Worse: Divorce Reconsidered. New York: W.W. Norton; 2002.

[18] Holtzman M. The family definitions continuum. Family Focus. 2005. June.

[19] How many people die each year from drug usage? (2016). http://teens.drugabuse.gov/nationaldrug-facts-week/how-many-people-die-each-year-drug-usage.

[20] Howard J. In A. Gore, T. Gore. The Spirit of Family. New York: Henry Holt (back cover); 2002.

[21] Marital events of Americans: 2009. American Community Survey Reports. http://www.census.gov/ $\operatorname{prod} / 2011 \mathrm{pubs} / \mathrm{acs}-13 . \mathrm{pdf}$.

[22] National marriage and divorce rate trends (2013). http://www.cdc.gov/nchs/nvss/marriage divorce tables.htm.

[23] Olson D.H., DeFrain J., Skogrand L. Marriages and Families: Intimacy, Diversity, and Strengths. New York: McGraw-Hill Higher Education; 2018.

[24] Popenoe D., Whitehead B.D. The State of Our Unions. Piscataway, NJ: National Marriage Project, Rutgers University; 2010.

[25] Rank M.R., Hirschl T.A. The economic risk of childhood in America: Estimating the probability of poverty across the formative years. Journal of Marriage and the Family, 1999: 61, 1058-1067. 
[26] Skogrand L., DeFrain N., DeFrain J., Jones J.E. (2008). Surviving and Transcending a Traumatic Childhood: The Dark Thread. London: Routledge/Taylor \& Francis Group; 2008.

[27] Statistical Abstract of the United States (2006). http://www.census.gov.

[28] Statistical Abstract of the United States (2008). http://www.census.gov.

[29] Statistical Abstract of the United States (2009). http://www.census.gov.

[30] U.S. Census Bureau (2016): Frequently asked questions. https://www.census.gov/hhes/www/ income/about/faqs.html.

[31] Waite L.J., Gallagher M. The Case for Marriage: Why Married People are Happier, Healthier, and Better off Financially. New York: Doubleday; 2000.

[32] Yoo Y.J., Lee I., Yoo G. How strong families encounter social challenges in the Republic of Korea. In J. DeFrain, S.M. Asay (Eds.) Strong Families Around the World: Strengths-based Research and Perspectives. London: Routledge/Taylor \& Francis Group, 2008.

[33] Zubkov V. Russian families: Historical and contemporary perspectives on problems and strengths. In J. DeFrain, S.M. Asay (Eds.) Strong Families Around the World: Strengths-based Research and Perspectives. London: Routledge/Taylor \& Francis Group, 2008.

DOI: 10.22363/2313-2272-2018-18-1-73-87

\title{
АМЕРИКАНСКАЯ СЕМЬЯ СЕГОДНЯ: ПАРАДОКС ТРАНСФОРМАЦИИ СЕМЬИ НА ФОНЕ СОХРАНЕНИЯ ПРЕЖНИХ СЕМЕЙНЫХ ЦЕННОСТЕЙ
}

\author{
Дж. ДиФрейн \\ Университет Небраски-Линкольна \\ Небраска 68588-0236 США \\ (e-mail: jdefrain1@unl.edu)
}

Как сегодня себя чувствует американская семья? Ответ зависит от того, кому именно вы задаете этот вопрос и сквозь призму какого подхода его рассматриваете - социального, политического или культурологического. Статья написана профессором кафедры исследований детства, юношества и семьи, который изучал соответствующую проблематику на протяжении более сорока лет. Автор счастливо женат более пятидесяти лет, вырастил трех дочерей и является членом расширенной семьи, имея трех зятьев и четырех внуков. В статье он принципиально отказывается от политизированного взгляда на семью, потому что подобные рассуждения обычно порождают споров больше, чем понимания ситуации. Хотя американские средства массовой информации склонны фокусироваться только на проблемах и порождают впечатление, что семьи, да и жизнь на планете в целом, находятся в серьезной опасности, автор, после сорока лет изучения крепких семей в США и по всему миру, убежден, что большинство семей в Америке хорошо справляются со своими задачами и членам таких семей нравится их совместная жизнь. Другие семьи справляются неплохо, а есть и те, что совсем не справляются. Дело в том, что у всех американских семей есть проблемы, как и у семей по всему миру, и с глобальной точки зрения нельзя признать все американские семьи крепкими. Однако все семьи в США имеют свои сильные стороны и используют их, чтобы справиться с теми сложностями, с которыми неизбежно сталкиваются. Автор начинает статью с макросоциологического подхода, а затем переходит к микро-социологическому взгляду на семью. Эти точки зрения дополняют друг друга и позволяют найти убедительные ответы на вопрос, как себя чувствуют американские семьи. Кроме того, сочетание этих подходов позволяет нам лучше понять тот парадокс, что семьи и семейные ценности сегодня меняются по очень многим направлениям, однако мы продолжаем жить, по сути, в тех же семьях, что и раньше.

Ключевые слова: семья; американская семья; политический подход; глобальный подход; макро-подход; микро-подход 